\title{
Potential effects of sea-level rise on plant productivity: species-specific responses in northeast Pacific tidal marshes
}

\author{
Christopher N. Janousek ${ }^{1,2, *}$, Kevin J. Buffington ${ }^{1,2}$, Karen M. Thorne ${ }^{2}$, \\ Glenn R. Guntenspergen ${ }^{3}$, John Y. Takekawa ${ }^{2,4}$, Bruce D. Dugger ${ }^{1}$ \\ ${ }^{1}$ Department of Fisheries and Wildlife, 104 Nash Hall, Oregon State University, Corvallis, OR 97331, USA \\ ${ }^{2}$ Western Ecological Research Center, US Geological Survey, Vallejo, CA 94592, USA \\ ${ }^{3}$ Patuxent Wildlife Research Center, US Geological Survey, Laurel, MD 20708, USA \\ ${ }^{4}$ Science Division, National Audubon Society, 220 Montgomery Street, San Francisco, CA 94104, USA
}

\begin{abstract}
Coastal wetland plants are adapted to varying degrees of inundation. However, functional relationships between inundation and productivity are poorly characterized for most species. Determining species-specific tolerances to inundation is necessary to evaluate sea-level rise (SLR) effects on future marsh plant community composition, quantify organic matter inputs to marsh accretion, and inform predictive modeling of tidal wetland persistence. In 2 macrotidal estuaries in the northeast Pacific we grew 5 common species in experimental mesocosms across a gradient of tidal elevations to assess effects on growth. We also tested whether species abundance distributions along elevation gradients in adjacent marshes matched productivity profiles in the mesocosms. We found parabolic relationships between inundation and total plant biomass and shoot counts in Spartina foliosa and Bolboschoenus maritimus in California, USA, and in Carex lyngbyei in Oregon, USA, with maximum total plant biomass occurring at 38, 28, and $15 \%$ time submerged, respectively. However, biomass of Salicornia pacifica and Juncus balticus declined monotonically with increasing inundation. Inundation effects on the ratio of belowground to aboveground biomass varied inconsistently among species. In comparisons of field distributions with mesocosm results, $B$. maritimus, $C$. lyngbyei and $J$. balticus were abundant in marshes at or above elevations corresponding with their maximum productivity; however, $S$. foliosa and S. pacifica were frequently abundant at lower elevations corresponding with sub-optimal productivity. Our findings show species-level differences in how marsh plant growth may respond to future SLR and highlight the sensitivity of high marsh species such as S. pacifica and J. balticus to increases in flooding.
\end{abstract}

KEY WORDS: Marsh organs $\cdot$ Plant biomass $\cdot$ Root-to-shoot ratio $\cdot$ Tidal wetlands $\cdot$ Zonation

\section{INTRODUCTION}

Vascular plant production is central to many important ecosystem processes in tidal wetlands. In addition to fueling coastal food webs (Parker et al. 2008), plant material also accumulates in sediments to contribute to the production of new soils (Neubauer 2008, Callaway et al. 2012). With long residence

*Corresponding author: janousec@onid.oregonstate.edu times in anoxic wetland sediments, non-labile organic matter constitutes a coastal carbon storage pool (Ouyang \& Lee 2014), while wetland loss can release large quantities of sequestered carbon into the atmosphere (Pendleton et al. 2012). The aboveground physical structure of salt marsh plants also provides other important coastal ecosystem services such as attenuating wave energy (Shepard et al. 2011), facil-

(C) C Janousek, K Buffington, J Takekawa, B Dugger 2016. Open Access under Creative Commons by Attribution Licence. Use, distribution and reproduction are unrestricted. Authors and original publication must be credited.

Publisher: Inter-Research · www.int-res.com 
itating sediment accretion (Gleason et al. 1979, Mudd et al. 2010), and providing habitat for wetlanddependent vertebrates (Sustaita et al. 2011).

Incorporation of estuarine plant material into wetland soils is one of the key elements of the biophysical processes that determine tidal wetland elevation relative to changing sea levels (Morris et al. 2002). For example, belowground root growth (or expansion of the base of shoots) contributes to the vertical growth of the marsh surface (Nyman et al. 2006, Cherry et al. 2009). However, vascular plant production is inundation-dependent, potentially leading to spatial heterogeneity in organic matter inputs to soils or aboveground trapping of inorganic sediment particles. Inundation gradients impact soil salinity and porewater sulfide concentrations (Mahall \& Park 1976a, Bertness \& Ellison 1987) — factors demonstrated to affect plant physiology (Bradley \& Dunn 1989, Hester et al. 2001).

Various inundation-productivity relationships have been reported for tidal marsh plants, including parabolic responses (Kirwan \& Guntenspergen 2012, 2015, Schile et al. 2014, Watson et al. 2015), linearly declining monotonic relationships (Voss et al. 2013), or exponentially declining relationships (Watson et al. 2014, Snedden et al. 2015). However, research to date has mainly focused on common marsh species found along the Atlantic coast of North America (but see Schile et al. 2014 for multi-species biomass data in California, USA). Since marshes in other regions of the world typically have different tidal ranges, species composition, and climatic regimes, relationships between inundation and plant growth may vary by species or region.

Accurate understanding of relationships between inundation and productivity is essential for implementation of mechanistic models of sea-level rise (SLR) effects because of the role that vegetation plays in the ecogeomorphic feedbacks that maintain marsh surface elevation in the tidal frame (Marani et al. 2010, Schile et al. 2014, Swanson et al. 2014). Morris et al. (2002) posited a unimodal relationship between productivity and inundation for Atlantic coast Spartina alternifora, suggesting that increasing inundation up to a threshold stimulates plant growth, thus enhancing marsh vertical growth, while flooding beyond this threshold negatively affects production and leads to the loss of the marsh as a stable ecosystem. Some wetland SLR models incorporate this basic unimodal functional relationship into projections of future marsh elevation (Schile et al. 2014, Swanson et al. 2014), but productivity in other marsh species may respond differently to changing inundation. In the ab- sence of sufficient in situ vertical growth to keep pace with SLR, marshes will need to migrate upslope to persist over the long term (Kirwan \& Megonigal 2013).

The present study determined how productivity in 5 common marsh species is affected by a wide range of inundation conditions at 2 estuaries on the Pacific coast of North America. Using intertidal mesocosms that isolated effects of submergence from potential inter-specific interactions, we quantified functional relationships between inundation and plant biomass and vegetative growth in individual species. To evaluate potential inundation effects on plant contributions to ecosystem processes, we tested the hypothesis that greater inundation had a disproportionately negative impact on belowground versus aboveground growth in each species. We additionally determined inundation effects on flower and seed production (reported in the supplementary material). Finally, we tested whether peak species abundance in the field (where both the biological interactions and various abiotic conditions potentially affect plant abundance) coincided with inundation levels of maximum productivity observed in the mesocosms.

\section{MATERIALS AND METHODS}

\section{Study sites}

We used mesocosms to grow plants at a range of elevations in 2 estuaries along the west coast of the United States during the 2014 growing season (Fig. 1). We deployed the mesocosms along the south-facing banks of Tule Slough in the Petaluma marsh, Sonoma County, California, USA $\left(38.1901^{\circ} \mathrm{N}, 122.5489^{\circ} \mathrm{W}\right)$ and Millport Slough in the Siletz Estuary, Lincoln County, Oregon, USA $\left(44.8877^{\circ} \mathrm{N}, 123.9971^{\circ} \mathrm{W}\right)$. Both sites are relatively undisturbed areas representative of brackish emergent tidal marsh in the northern San Francisco Bay estuary and outer coast of the US Pacific Northwest with mixed semi-diurnal tides.

Vegetation at Petaluma marsh is dominated by perennial pickleweed Salicornia pacifica (Takekawa et al. 2013), but includes other common species such as coyote brush Baccharis pilularis DC., jaumea Jaumea carnosa (Lessing) A. Gray, California cordgrass Spartina foliosa Trin., and saltmarsh bulrush Bolboschoenus maritimus (L.) Palla. The site has a tidal range of $1.92 \mathrm{~m}$ between mean lower low water (MLLW) and mean higher high water (MHHW) (NOAA tide station 9415423, http://tidesandcurrents. noaa.gov). The region has a Mediterranean climate 


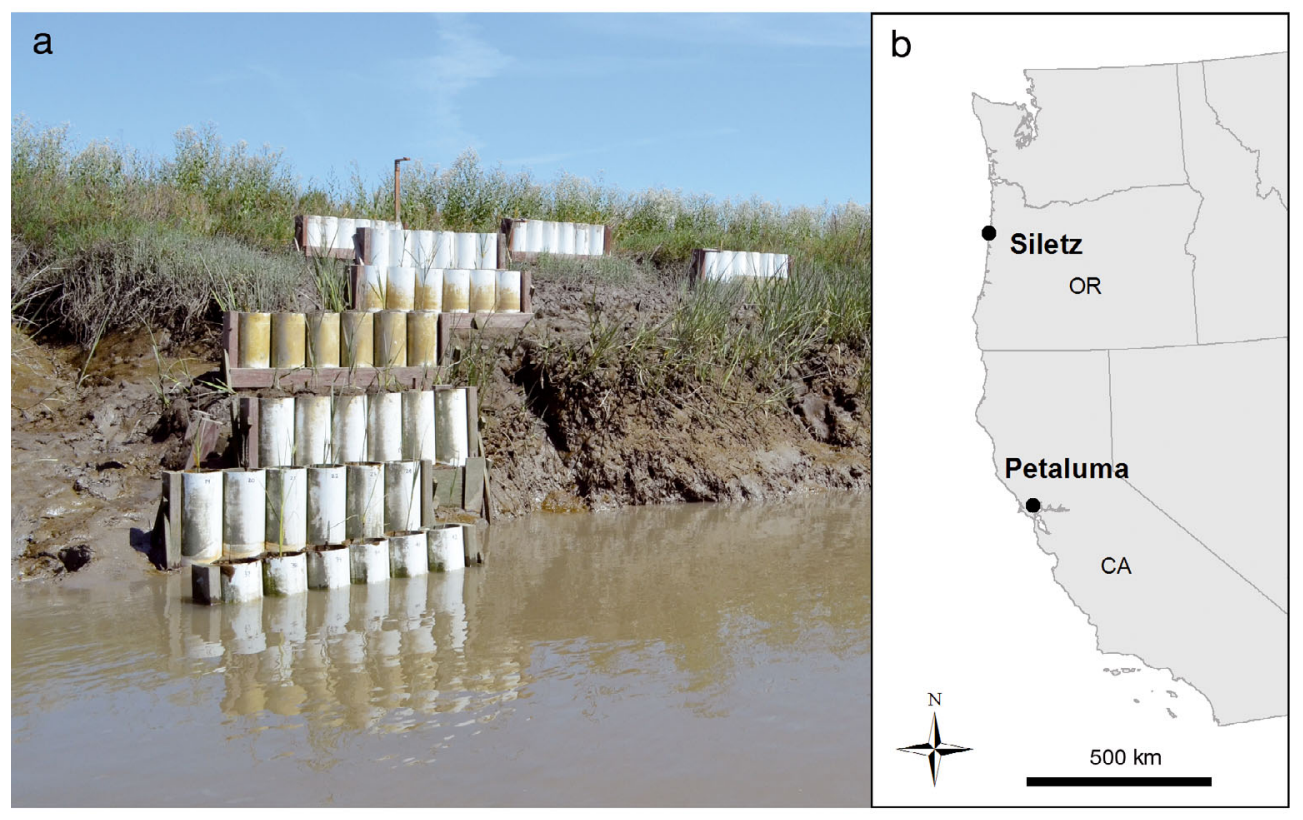

Fig. 1. (a) Mesocosms at Petaluma, and (b) study locations at Petaluma marsh, California, and Siletz marsh, Oregon, along the west coast of the USA. Photo: C. N. Janousek with pronounced wet and dry seasons. Mean monthly salinities during higher tides range from about 3 ppt in late winter to 25 ppt in fall (Takekawa et al. 2013). During our study period, mean water column salinity at Petaluma at the beginning of the growing season was mesohaline (6-10 ppt in early April) but gradually increased to euhaline conditions by late June ( $\geq 30 \mathrm{ppt}$ ). Mean water temperatures in Tule Slough ranged from 13.3 to $23.6^{\circ} \mathrm{C}$ (Fig. S1 in Supplement 1 at www.int-res.com/articles/suppl/ m548p111_supp.pdf). Average daily air temperatures for the study period (excluding a 13 d data gap) at a nearby weather station in the Petaluma Valley ranged from 8.1 to $21.9^{\circ} \mathrm{C}$; total precipitation during the same period totaled $72 \mathrm{~mm}$ (CIMIS station 144, www.cimis.water.ca.gov).

The Siletz Estuary is a macrotidal, drowned rivermouth estuary on the central Oregon coast (Lee \& Brown 2009). In Millport Slough, emergent wetland vegetation is composed of several dozen herbaceous and woody species with tufted hairgrass Deschampsia cespitosa (L.) Beauv., Baltic rush Juncus balticus Willdenow ssp. ater (Rydb.) Snogerup, Pacific silverweed Potentilla anserina L. and creeping bentgrass Agrostis stolonifera L. being common (Brophy et al. 2011). At nearby Salmon River Estuary and Depot Bay (to the north and south of Siletz Bay, respectively), MLLW-MHHW tidal ranges are 2.17 and $2.51 \mathrm{~m}$, respectively (NOAA tide stations 9436381 and 9435827; http://tidesandcurrents.noaa.gov). The Oregon coast has a Maritime climate with higher total annual rainfall than central California. During our study period in 2014, Siletz was oligohaline until late May (<5 ppt) and mean water column salinities did not exceed 20 ppt for the rest of the experiment. Daily mean water temperatures in Millport Slough during the study period ranged from 9.4 to $20.7^{\circ} \mathrm{C}$ (Fig. S1 in Supplement 1). Mean daily air temperatures at nearby South Beach along the central Oregon coast ranged from 8.7 to $22.5^{\circ} \mathrm{C}$; total precipitation at South Beach during the study period was $190 \mathrm{~mm}$ (http://weather.hmsc.oregonstate.edu/ weather/weatherproject/hmsc_weather.html).

\section{Experimental design}

The mesocosms in this study followed the 'marsh organ' designs used previously in studies of tidal inundation effects on marsh productivity in the eastern USA (e.g. Voss et al. 2013, Kirwan \& Guntenspergen 2015), except that individual rows of the 'organs' (different elevation treatments) were physically separated and installed along natural elevation gradients found at the edges of tidal channels to accommodate the larger tidal amplitude of north Pacific marshes. Each 'module' in the experiment consisted of 6 vertical PVC pipes $(15 \mathrm{~cm}$ diameter, $40 \mathrm{~cm}$ length) linearly arranged in a wooden frame. All pipes were open on the bottom, with the bottom of the tubes resting on ambient sediment, enabling physical support of the sediment inside the tubes and allowing vertical (but not horizontal) hydrologic connectivity with the sediment below (see discussion in 
Kirwan et al. 2013). The mesocosm approach allows precise quantification of inundation duration and the ability to carefully quantify belowground biomass responses (because roots of experimental plants are separated from other plants), but may artificially slow soil drainage and isolates plants from belowground interactions with neighboring vegetation. We filled the mesocosms completely with sediment obtained from the adjacent tidal channels.

We deployed the modules at 6 (Siletz) or 7 (Petaluma) elevations spanning the range of tidal elevations over which tidal marsh vegetation is typically found at the 2 sites, with the uppermost modules above the nearby marsh plain and the lowest modules at approximately the lowest extent of marsh vegetation (Fig. 1). The vertical separation between treatment levels was $27 \mathrm{~cm}$ at Petaluma and $33 \mathrm{~cm}$ at Siletz. We installed 3 modules per elevation at Petaluma (21 total modules) and 2 modules per elevation at Siletz (12 total modules), giving 6 replicate mesocosms per elevation per species. Water level data collected during the experiment (described below) showed that the highest platform level at Siletz did not flood during the duration of the experiment, so we omitted those samples from further analysis.

To determine the elevation of each installed module, we averaged multiple survey-grade Real-Time Kinematic (RTK) GPS measurements using Leica Viva GS15 and RX1250X GNSS rovers (Leica Geosystems) conducted over the course of the experiment ( $\mathrm{n}=4-11$ per module). Rover positions were received from the Leica Smartnet RKT network in California (https://www.smartnetna.com/index.cfm) and the Oregon Real-Time RTK network (www. oregon.gov/ODOT/HWY/theorgn/Pages/Maps.aspx). We determined orthometric heights (North American Vertical Datum of 1988, NAVD88) with geoid models 09 (Petaluma) and 12A (Siletz). Rover precision was determined with replicate measurements at a reference benchmark and it varied among the 2 rovers between 0.013 and $0.023 \mathrm{~m}$ (standard deviation). We measured probable minor sinking of some platforms $(<10 \mathrm{~cm})$ over the course of the experiment; thus we used the mean elevation of all measurements of each module for analyses.

We measured changes in water column conditions in the adjacent tidal channels at each site over the course of 1 growing season. We determined water levels every 12 min with Solinst water level loggers (Levelogger; Solinst Canada) set inside stilling wells, with sensor positions $10 \mathrm{~cm}$ below the lowest experimental elevation at each site. We corrected raw water level data for atmospheric variation with a time series of local barometric pressure readings obtained with additional loggers above the intertidal. We determined the percent time each individual module was inundated over the course of the experiments from the NAVD88 elevations of each module and the time series of water level at each site. We recorded water column conductivity and temperature with Odyssey conductivity sensors (Dataflow Systems) also deployed at the elevation of the lowest module. We first converted raw logger output (specific conductance values) to salinity and then (because logger accuracies can vary by several percent from sensor to sensor), obtained final time series by adjusting logger salinity and temperature values with logger-specific linear regression equations generated across a range of temperatures and salinities under carefully measured laboratory conditions (Janousek \& Mayo 2013).

\section{Plant cultivation}

We used species that are major components of tidal marsh floras in their respective regions. At Petaluma we collected small shoots of Spartina foliosa (Poaceae) and Bolboschoenus maritimus (Cyperaceae) including intact sections of rhizome in March 2014, and placed them in Cone-tainers (Stewe \& Sons) with sediment from the field site, to grow in a greenhouse at the US Geological Survey field station in Vallejo, California, USA. We also collected $\sim 10$ to $20 \mathrm{~cm}$ long green shoot cuttings of Salicornia pacifica (Chenopodiaceae) during the same time period and placed the stems directly into sediment to promote root formation. We grew plants in shallow plastic bins with the bottom half of the Cone-tainers submerged in fresh water. We periodically watered all plants with fresh water, until about $1 \mathrm{wk}$ prior to transplantation, at which time we raised salinity to $5 \mathrm{ppt}$ and then 10 ppt. We did not note any obvious shock to the plants by raising the salinity over the course of a week. After 2 to $4 \mathrm{wk}$ in the greenhouse, on 2 April we planted healthy plants (with single shoots) randomly across elevation treatments and mesocosm position within the modules. We sacrificed 6 additional plants of each species to estimate initial dry mass at the time of planting. Total dry mass values (mean \pm $\mathrm{SD}$ ) were $0.79 \pm 0.27,2.30 \pm 1.20$, and $0.29 \pm 0.13 \mathrm{~g}$ for $S$. foliosa, $B$. maritimus and $S$. pacifica, respectively.

At Siletz, we collected small marsh plugs $(\sim 10 \times$ $10 \mathrm{~cm}, 10 \mathrm{~cm}$ deep) containing roots, rhizomes and shoots of Carex lyngbyei (Cyperaceae) and Juncus balticus (Juncaceae) on 11 April 2014 and added them to pots for maintenance under fresh water in an 
outdoor greenhouse at Oregon State University in Corvallis, until transplantation into the field. We removed shoots from non-target species that grew from the plugs. The site was relatively fresh at the time of transplantation with mean daily salinities ranging from 0.7 to $4.8 \mathrm{ppt}$ the first week after planting. We removed all but 2 or 3 shoots of C. lyngbyei and $J$. balticus, respectively, before planting the 72 replicate plugs on 23 April, assigning plants to mesocosms randomly. We sacrificed 6 additional plants of each species to estimate initial dry mass (shoots only) at the time of planting. Shoot dry mass (mean \pm SD) was $0.47 \pm 0.06$ and $0.64 \pm 0.28 \mathrm{~g}$ for $J$. balticus and C. lyngbyei, respectively.

\section{End of growing season measurements}

We surveyed growth and health of the plants by monitoring them every 2 to $4 \mathrm{wk}$ from planting until the end of the experiments. At approximately the end of the growing season (11-12 August for Petaluma; 26 August for Siletz), we assessed plant status (healthy, almost dead, dead, missing), the total number of shoots (for all species except $S$. pacifica), incidence of flower production, and number of seeds ( $J$. balticus only) in each mesocosm. We then harvested the plants to determine above- and belowground biomass. We washed plants in tap water over 500 or $1000 \mu \mathrm{m}$ sieves to remove soil and organic debris from belowground roots and rhizomes and removed belowground biomass of non-target species (e.g. Triglochin maritima) that were present in the Siletz samples. We did not retain very small root fragments during sample processing, which constituted a small fraction of total root mass. We dried above- and belowground fractions at about 55 to $60^{\circ} \mathrm{C}$ for approximately $4 \mathrm{~d}$ prior to weighing on an analytical balance (model AND HR-202i; A\&D Company). At Siletz, we recovered above- and belowground biomass for all replicates in the experiment. At Petaluma, $14 \%$ of plants were missing shoots (or all structures), and many of these replicates died during the course of the experiment. However, we treated missing structures at the end of the study as missing values, not as zero values, because many plants grew for weeks or months before they were lost from the mesocosms and therefore had net gains in biomass. We reanalyzed these Petaluma samples by treating missing structures as zero biomass or zero shoot counts, but this had no qualitative, and little quantitative, effect on study results (Supplement 2 at www. int-res.com/articles/suppl/m548p111_supp.pdf).

\section{Species distributions in the adjacent marshes}

We conducted field surveys with $0.25 \mathrm{~m}^{2}$ quadrats to compare in situ distributions of the 5 species with the mesocosm results. At Petaluma, we surveyed percent cover of $S$. foliosa, $B$. maritimus and $S$. pacifica in 120 plots from 14 to 17 July. Because most of the site consists of a relatively high-elevation marsh plain dominated by $S$. pacifica, we sampled 30 transects ( $6 \mathrm{~m}$ length) randomly positioned along $3 \mathrm{ma}-$ jor tidal channels in the area to capture enough plots across a range of elevations. Along each transect (oriented perpendicular to the channel axis) we measured percent cover and plot elevation with RTK GPS in 4 plots spaced about $2 \mathrm{~m}$ apart from the vegetation boundary at the channel edge onto the marsh plain.

At Siletz, we sampled percent cover of C. lyngbyei and $J$. balticus in 126 plots between 25 August and 4 September along parallel transects spaced relatively uniformly across the marshes between Millport Slough and the Siletz River. Plots were sampled typically at $\sim 100 \mathrm{~m}$ intervals. As at Petaluma, we measured plot elevation with RTK GPS. Most of the vegetated tidal wetland surveyed at the site was relatively high in elevation, so the surveys captured only a subset of the elevation range present in the mesocosm experiment. At both sites we used RTK-derived elevations with local water level data to estimate duration of inundation for each field plot. We also determined the elevation of each plot relative to local MHHW using tidal datums in Brophy et al. (2011) for Siletz and published geodetic and tidal elevations (www.ngs.noaa.gov) for 3 tidal benchmarks near the Petaluma marsh. Site-specific relationships between MHHW and time inundated are shown in Fig. S2 in Supplement 3 at www.int-res.com/articles/suppl/ m548p111_supp.pdf.

\section{Statistical analyses}

We tested the effects of percent time inundated on end-of-growing-season total plant dry mass, shoot dry mass, root + rhizome dry mass, natural log-transformed ratios of root-to-shoot biomass (Hedges et al. 1999), and total shoot counts, with a second order polynomial regression for each species (function 'lm', package 'base', R v.3.1.2, The Comprehensive R Archive Network; https://cran.r-project.org). We used polynomial regression to accommodate non-linear relationships, consistent with previous studies (e.g. Kirwan \& Guntenspergen 2012). For total biomass and shoot count data, we estimated the inundation level 
corresponding with maximum productivity for those species exhibiting distinct unimodal relationships.

To estimate the elevations at which maximum abundance occurred for each species along elevation gradients at the sites, we used non-linear quantile regression splines (functions 'rq' and 'ns' in packages 'quantreg' and 'splines', R v.3.1.2). We used the upper $90^{\text {th }}$ percentile of the distribution (tau $=0.9$ ) to estimate maximum percent cover, because some plots may have had low cover at otherwise favorable elevations due to other factors affecting species distribution (e.g. Cade \& Noon 2003). We used natural cubic splines, a method which uses polynomial fits to discreet quantiles of the distribution depending on the number of 'internal knots' selected, while constraining the fit beyond the ends of the distribution ('boundary knots') to be linear. We used 4 internal knots $(\mathrm{df}=5)$ to fit the splines, which generally provided satisfactory curve smoothness but did not overfit noise in the distribution. We qualitatively compared inundation-productivity relationships for each species from the mesocosms (estimated from the polynomial relationships with total biomass) with abundance distributions in the field.

\section{RESULTS}

\section{Plant survivorship and growth}

Plant survivorship in the experiments varied by species and inundation treatment. At Petaluma, Bolboschoenus maritimus shoots grew rapidly during the first month of the experiment, but ceased growing taller thereafter; Salicornia pacifica and Spartina foliosa grew steadily over the growing season (data not shown). By the end of the growing season most individuals of $S$. pacifica and $S$. foliosa were alive, but 36 and $21 \%$ of the mesocosms, respectively, had dead plants or were missing all shoots. B. maritimus survivorship was poor: $12 \%$ of plants were alive, $33 \%$ were near death, $45 \%$ were dead, and $10 \%$ were missing shoots. In contrast, all Carex lyngbyei and Juncus balticus plants survived at Siletz.

\section{Plant biomass}

Growth responses to the inundation gradients in our experiments varied by species. End-of-season total dry mass of $S$. foliosa and B. maritimus had unimodal relationships with tidal inundation (Fig. 2) $-S$. foliosa: $\mathrm{R}^{2}{ }_{\text {adj }}=0.60, \mathrm{p}<0.0001 ; B$. maritimus: $\mathrm{R}^{2}{ }_{\text {adj }}=0.33, \mathrm{p}=$
0.0004). Peak dry mass was estimated at $38 \%$ inundation for $S$. foliosa and $28 \%$ for B. maritimus. Total dry biomass of $S$. pacifica was highest at about 0 to $10 \%$ inundation, but non-linearly declined with increased submergence $\left(\mathrm{R}_{\text {adj }}^{2}=0.61, \mathrm{p}<0.0001\right)$. S. pacifica total mass was very low when inundation exceeded about $30 \%$. Total dry biomass of $J$. balticus was variable (though generally high) between 0 and $5 \%$ flooding, but declined at greater levels of inundation, reaching nearly zero above $35 \%$ submergence $\left(R^{2}{ }_{\text {adj }}=0.49\right.$, $p<$ 0.0001). The response of $C$. lyngbyei to flooding followed a unimodal pattern with maximum total mass at $15 \%$ inundation $\left(\mathrm{R}_{\text {adj }}^{2}=0.31, \mathrm{p}=0.003\right)$. For all species, above- and belowground dry mass had similar functional relationships with inundation as observed with total dry mass (Fig. 2, Supplement 2).

Allocation of biomass between belowground versus aboveground structures varied non-linearly with tidal flooding, but again patterns differed among species (Fig. 3). S. pacifica tended to have low rootto-shoot ratios at low inundation, indicating allocation of most resources to shoot growth. At greater inundation, root-to-shoot ratios were higher $\left(\mathrm{R}^{2}{ }_{\text {adj }}=\right.$ $0.18, \mathrm{p}=0.02)$. In B. maritimus, $S$. foliosa and $J$. balticus, root-to-shoot ratios were lowest at intermediate levels of inundation but higher under either infrequent or frequent inundation $\left(B\right.$. maritimus: $\mathrm{R}_{\text {adj }}=$ $0.31, \mathrm{p}=0.0007 ;$ S. foliosa: $\mathrm{R}^{2}{ }_{\mathrm{adj}}=0.15, \mathrm{p}=0.02$; J. balticus: $\left.\mathrm{R}^{2}{ }_{\text {adj }}=0.15, \mathrm{p}=0.04\right)$. In C. lyngbyei, rootto-shoot ratios declined monotonically with increasing inundation $\left(\mathrm{R}^{2}{ }_{\text {adj }}=0.33, \mathrm{p}=0.002\right)$.

\section{Vegetative growth and fecundity}

Inundation effects on end-of-growing season total shoot counts in S. foliosa, B. maritimus, C. lyngbyei and $J$. balticus were similar to species-specific results obtained for total dry mass (Fig. 4). B. maritimus and $S$. foliosa produced the most shoots at intermediate levels of inundation $\left(\mathrm{R}_{\text {adj }}^{2}=0.15, \mathrm{p}=0.02\right.$ and $\mathrm{R}^{2}{ }_{\text {adj }}=$ $0.35, p=0.0002$, respectively). Maximum shoot production was estimated at $38 \%$ inundation in $S$. foliosa and $36 \%$ in B. maritimus. Shoot production in C. lyngbyei also had a unimodal relationship with flooding $\left(\mathrm{R}_{\text {adj }}^{2}=0.27, \mathrm{p}=0.006\right)$, and maximum shoot production occurred at $7 \%$ inundation. $J$. balticus shoot production declined nearly linearly from the lowest to highest levels of inundation $\left(R^{2}\right.$ adj $\left.=0.30, p=0.003\right)$. Inundation effects on plant flowering incidence for all species and on seed production in $J$. balticus are presented in Supplement 4 at www.int-res.com/ articles/suppl/m548p111_supp.pdf. 


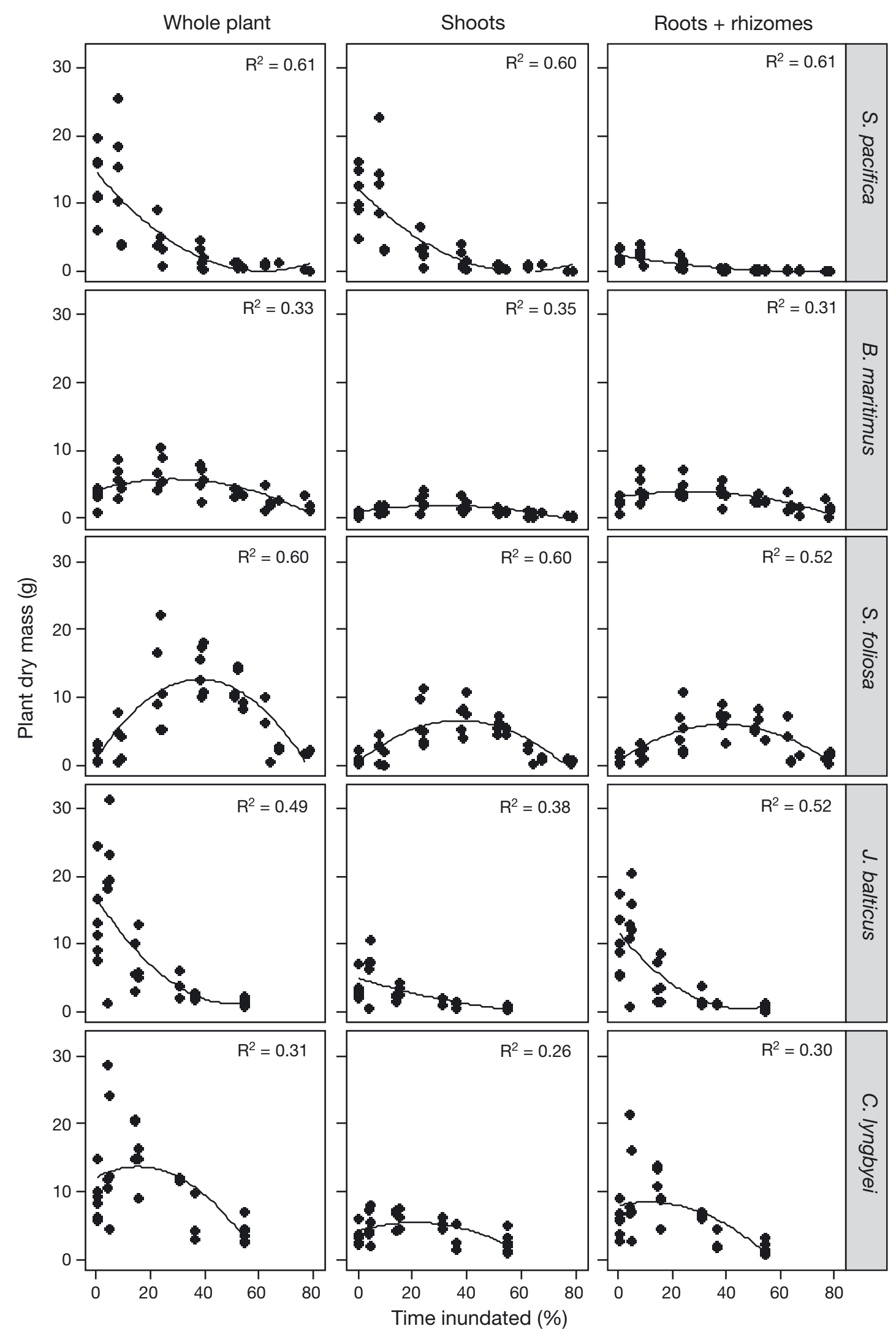

Fig. 2. End-of-growing-season dry mass of whole plants, shoots and roots + rhizomes relative to total time inundated in Salicornia pacifica, Bolboschoenus maritimus, and Spartina foliosa at Petaluma, and Juncus balticus and Carex lyngbyei at Siletz. Lines and adjusted $\mathrm{R}^{2}$ values are least-squares second order polynomials fit to the data 


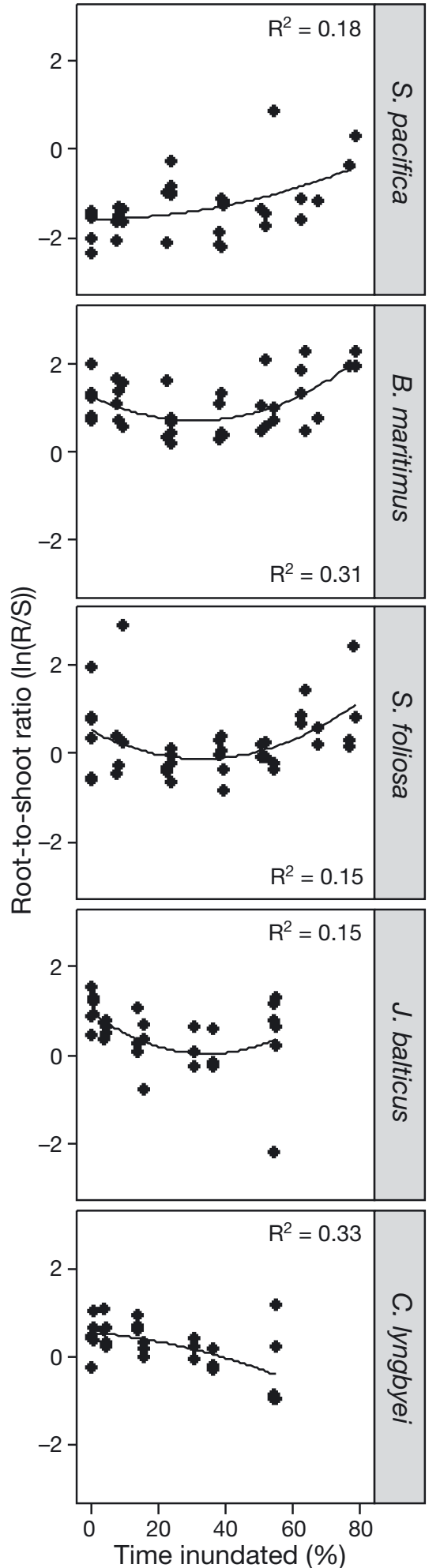

Fig. 3. Inundation effects on end-of-growing season rootto-shoot (R/S) ratios in Salicornia pacifica, Bolboschoenus maritimus, and Spartina foliosa from Petaluma, and Juncus balticus and Carex lyngbyei from Siletz. Lines and adjusted $\mathrm{R}^{2}$ values are least-squares second order polynomials fit to the data
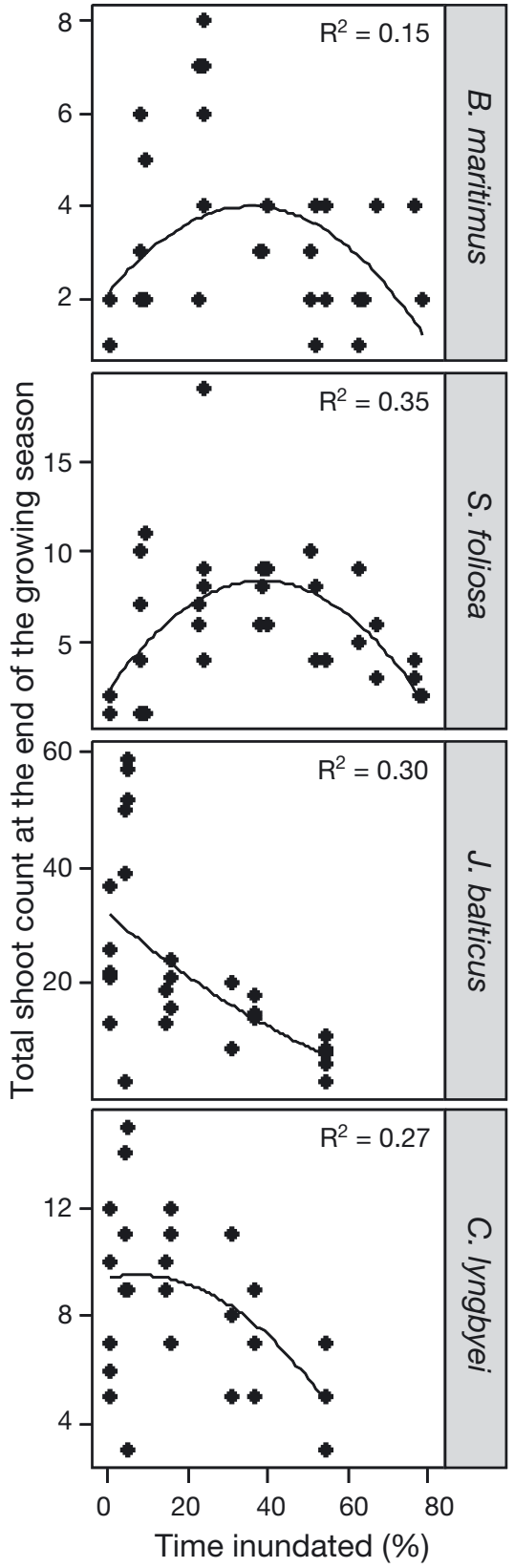

Fig. 4. Total shoot count in Bolboschoenus maritimus and Spartina foliosa along inundation gradients at Petaluma, and in Juncus balticus and Carex lyngbyei along inundation gradients at Siletz. Lines and adjusted $\mathrm{R}^{2}$ values are leastsquares second order polynomials fit to the data

\section{Plant distributions in adjacent marshes}

Species in the study tended to occupy distinct tidal zones, particularly at Petaluma. S. foliosa and B. maritimus frequently occurred in monospecific patches at lower tidal elevations, with the latter sometimes co-occurring with $S$. pacifica. S. foliosa was present 


\section{S. pacifica}
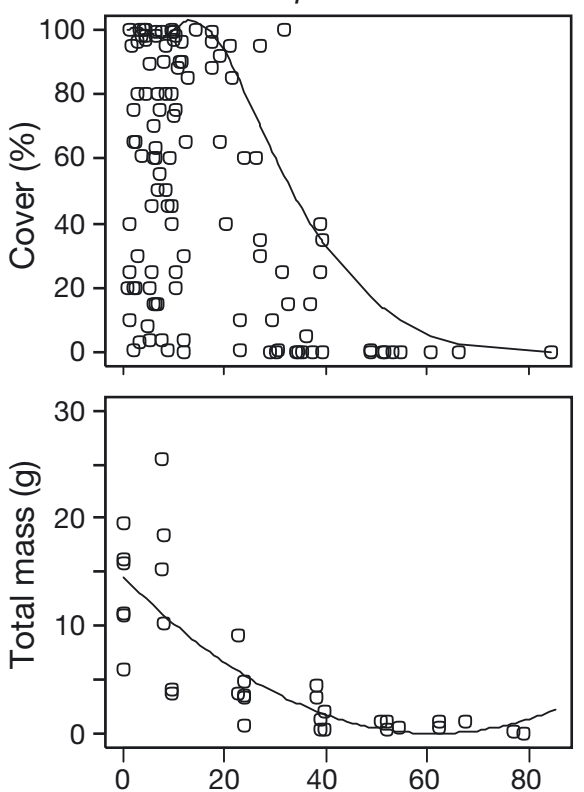

B. maritimus
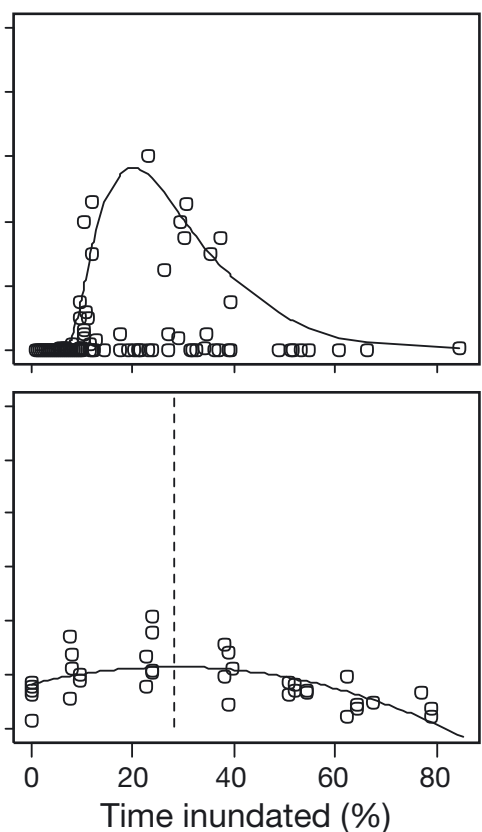

S. foliosa
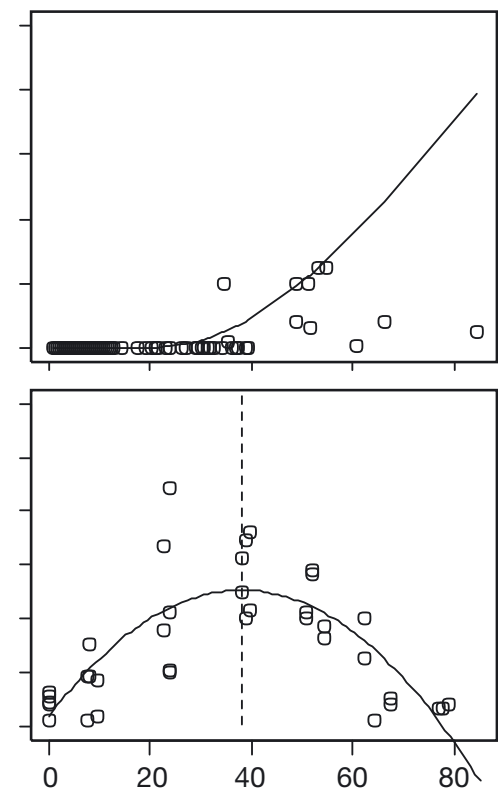

Fig. 5. Comparison of in situ species cover versus inundation, along with indundation-biomass relationships in the mesocosm experiments at Petaluma marsh. Distribution of maximum cover with inundation was modeled using $90 \%$ quantile natural regression splines with 4 internal knots (top panels, solid lines); biomass was modeled with least-squares second order polynomials (bottom panels, solid lines), and estimated peak productivities for Spartina foliosa and Bolboschoenus maritimus are shown with vertical dashed lines. The increasing tail of the $S$. foliosa model fit at high inundation is thought to be an artifact of fitting quantile regression to a limited sample size; higher inundation usually corresponds with unvegetated mudlfat or tidal channels at the site

between -0.46 and $-1.48 \mathrm{~m}$ MHHW, corresponding to 35 to $84 \%$ inundation (Fig. 5, Supplement 3). However, most occurrences of the species were at greater levels of inundation $(\geq 49 \%)$. B. maritimus was distributed from +0.09 to $-1.48 \mathrm{~m}$ MHHW, with moderate to high cover $(\geq 25 \%)$ occurring between -0.02 and $-0.51 \mathrm{~m}$ MHHW (10-37\% inundation). Peak abundance was estimated by splinal quantile regression to occur at $\sim 20 \%$ flooding. Cover was zero or at trace levels at $>40 \%$ flooding. S. pacifica tended to occur higher than the other species at the site, though it had a broad distribution, occurring from +0.25 to $-0.77 \mathrm{~m}$ relative to MHHW. It occurred as monospecific assemblages or mixed with other species. Its highest abundance ( $\geq 50 \%$ cover) occurred between +0.21 and $-0.41 \mathrm{~m} \mathrm{MHHW}$, elevations that corresponded to 1 to $32 \%$ inundation. Splinal regression summaries are reported in Table S5 in Supplement 5 at www.int-res.com/articles/suppl/m548p111_ supp.pdf.

At Siletz, C. lyngbyei often occupied lower elevation tidal marsh, ranging from near monocultures to mixed assemblages with other species. It was distributed from +0.24 to -0.47 m relative to local MHHW (Fig. 6).
It had high cover ( $\geq 50 \%$ ) between -0.13 and $-0.47 \mathrm{~m}$ MHHW but we did not survey any plots lower than $-0.47 \mathrm{~m} \mathrm{MHHW}$ at the site. The elevation range of high cover corresponded with 5 to $18 \%$ inundation. $J$. balticus typically occurred as one component of mixed species plots. It was present in plots ranging from +0.38 to $-0.21 \mathrm{~m}$ MHHW, with high abundance $(\geq 50 \%$ cover) occurring from +0.21 to $-0.20 \mathrm{~m}$ MHHW (corresponding to 1 to $7 \%$ inundation).

\section{DISCUSSION}

We found major differences in responses to inundation gradients among the Pacific coast marsh species examined in this study. Three species had unimodal functional relationships with inundation but peak production at different tidal levels, while production in 2 species declined monotonically with increasing inundation. Ratios of root-to-shoot dry mass varied non-linearly with tidal inundation and inconsistently among species. By comparing plant distributions in adjacent marshes with mesocosm results, we determined that 2 species common in Cali- 
J. balticus

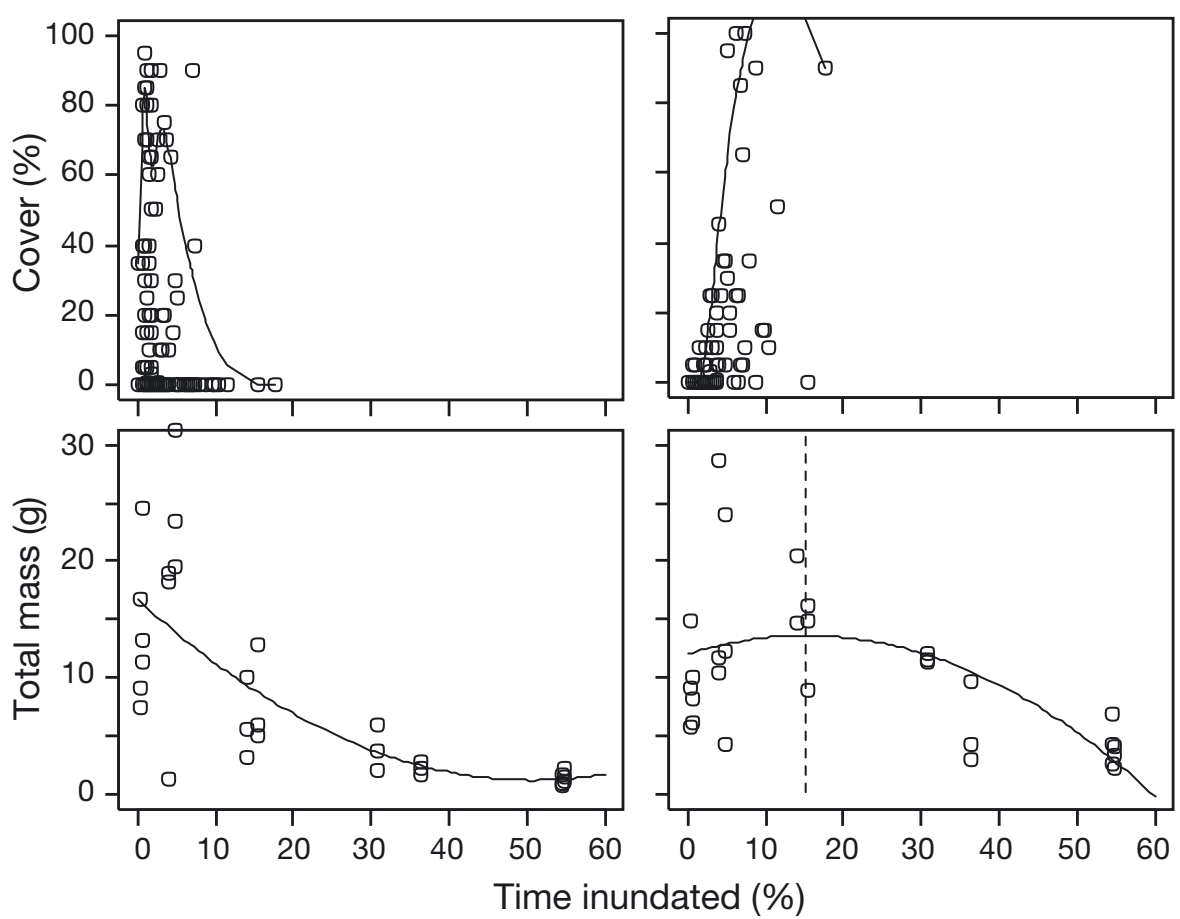

Fig. 6. Comparison of in situ species cover versus inundation, along with indundation-biomass relationships in the mesocosm experiments at Siletz. Distribution of maximum cover with inundation was modeled using $90 \%$ quantile natural regression splines with 4 internal knots (top panels, solid lines), biomass was modeled with least-squares second order polynomials (bottom panels, solid lines), and estimated peak productivity for Carex lyngbyei is shown with a vertical dashed line fornia marshes - Salicornia pacifica and Spartina foliosa - were often abundant at intertidal elevations below their optimal productivity. The other species in the study had highest abundance in the field at elevations corresponding with their preferred inundation levels. These divergent functional responses to inundation, and distribution relative to optimal inundation conditions, suggest unique species responses to future sea-level rise on the Pacific coast.

\section{Biomass-inundation relationships}

Middle- to lower-marsh species in our study (Bolboschoenus maritimus and S. foliosa in California; Carex lyngbyei in Oregon) had unimodal productivity-inundation relationships, qualitatively similar to previous findings for Schoenoplectus americanus on the Atlantic coast of the USA (Kirwan \& Guntenspergen 2012, 2015). Although the 3 Pacific coast species had similarly-shaped functional responses to inundation, estimated peak biomass occurred at different inundation levels. S. foliosa had the greatest tolerance of higher inundation, consistent with its usual occurrence at lower elevations than other species in many California marshes (Zedler 1977, Takekawa et al. 2013).

Productivity of 2 common high marsh species $(S$. pacifica in California and Juncus balticus in Oregon) declined monotonically with increasing inundation. Both species maintained relatively high productivity at $<5$ to $10 \%$ inundation, but growth declined steeply with increasing submergence. A recent greenhouse study with adult $S$. pacifica also found that plant height declined monotonically with increasing inundation (Woo \& Takekawa 2012). S. pacifica dominates tidal marsh vegetation throughout much of California where it typically occurs on the high marsh plain. At Petaluma for example, it is abundant between mean high water (MHW) and MHHW (Takekawa et al. 2013). S. pacifica is a foundation species in many California tidal wetlands, providing important habitat for marsh-dependent wildlife (Thorne et al. 2012) and likely contributing large amounts of organic matter to salt marsh soils. J. balticus is a common species in Pacific Northwest tidal marshes, found particularly in lower-salinity, high-elevation soils (Janousek \& Folger 2014).

Like $S$. pacifica and J. balticus in this study, experimental work with the high marsh species Spartina patens from Chesapeake Bay showed declining production with increasing inundation (Kirwan \& Guntenspergen 2015). Productivity in the lower-elevation Atlantic species Spartina alterniflora was initially hypothesized to have a unimodal relationship with inundation (Morris et al. 2002), though experimental data from North Carolina did not strongly support this relationship (Voss et al. 2013) and data from New 
England and Louisiana show a monotonic decline in production with greater flooding (Watson et al. 2014, Snedden et al. 2015).

Our species-specific data on productivity-inundation relationships have several implications for understanding SLR effects on Pacific coast tidal wetlands. First, similar to emerging patterns for Atlantic salt marshes, our results suggest that marshes with differing species composition may have fundamentally different responses to changing inundation gradients. For instance, in S. pacifica-dominated high marshes, small increases in relative SLR are expected to reduce, not enhance, productivity, in contrast to predictions of the conceptual model in Morris et al. (2002). At Petaluma, relative SLR of $20 \mathrm{~cm}$ would nearly double inundation times at current MHHW (10 to $19 \%$ ) with an expected decrease in $S$. pacifica total biomass. Loss of local productivity may initiate a negative feedback between inundation and marsh accretion because of a reduction in inorganic particle trapping and a decrease in organic matter inputs to marsh soils (Morris et al. 2002).

Second, our data suggest that mechanistic models of SLR may be more effective if they account for differences in vegetation composition and their feedbacks to tidal marsh elevation. Under conditions of constant inorganic sediment availability, spatial differences in marsh production can affect the rate at which marshes are impacted by rising sea levels (Schile et al. 2014). The WARMER model, used to estimate SLR effects on Pacific coast marshes, currently uses a unimodal productivity-inundation relationship hypothesized for S. alterniflora which places maximum production at mid-marsh elevations and assumes that productivity approaches zero at the upland-marsh boundary (Swanson et al. 2014). This generalized functional relationship may work well for modeling sites dominated by similarly-responding species such as C. lyngbyei in some Pacific Northwest estuaries (Hutchinson 1988), but may inaccurately estimate organic matter contributions to soil formation for areas dominated by high marsh species such as S. pacifica in California, J. balticus in some mature Pacific Northwest marshes, or S. patens in some Atlantic marshes (Kirwan \& Guntenspergen 2015). These species have maximum production essentially at near-zero inundation levels, a substantial difference from the assumptions of some current models.

Finally, our data have implications for potential changes in tidal marsh plant composition that may occur with relative sea-level rise. One expected consequence is that the inundation gradients affecting species distributions in tidal marshes may change in magnitude or spatial location, leading to changes in the relative abundance of marsh species. For instance, in California, S. pacifica-dominated marshes that gradually become subject to higher inundation may be eventually colonized by Spartina foliosa or other more flooding-tolerant species such as the nonnative $S$. alterniflora and $S$. alterniflora $\times$ foliosa hybrid that have recently invaded the San Francisco Bay estuary (Callaway \& Josselyn 1992, Daehler \& Strong 1997). The pace and magnitude of compositional changes will likely be affected by how quickly individual species more tolerant of inundation are able to disperse to areas occupied by species less tolerant of flooding and outcompete established, but less productive, vegetation. Where Spartina spp. cannot invade, drowning $S$. pacifica marshes may become unvegetated mudflat.

Changes to marsh assemblage composition are also likely to be determined by how broadly tolerant different species are to a range of inundation conditions, not just differences in their inundation optima. In the diverse tidal marshes of the Pacific Northwest, for example, the distribution of some species such as Agrostis stolonifera or Triglochin maritima were found to be relatively insensitive to differences in marsh elevation and might therefore be little affected by increasing inundation (Janousek \& Folger 2014). More generally, species largely restricted to high marsh elevations may be particularly vulnerable to SLR because small increases in relative SLR could result in a several-fold increase in flooding.

One additional important consequence of elevated SLR may be changes to other abiotic factors that affect plant composition, including the potential for increasing wetland salinity to accompany SLR (Cloern et al. 2011, Ross et al. 2015). Rising salinity may favor more salt tolerant species (Ryan \& Boyer 2012, Snedden et al. 2015), decrease productivity (Pearcy \& Ustin 1984, Hester et al. 2001), and reduce plant diversity in marsh assemblages (Engels \& Jensen 2009). Increasing inundation may also be associated with lower soil redox potential (Bertness \& Ellison 1987), which in turn may correspond with differences in marsh species composition (Sánchez et al. 1998).

We hypothesized that root-to-shoot ratios would decline with increasing inundation as observed in several other tidal marsh studies (e.g. Rozema \& Blom 1977, Kirwan \& Guntenspergen 2012, Janousek \& Mayo 2013, Langley et al. 2013). However, of the 5 species examined, this response was only observed in C. lyngbyei. In contrast, $S$. pacifica root-to-shoot ratios appeared to increase with greater inundation, 
and ratios in B. maritimus, $J$. balticus and $S$. foliosa increased above $\sim 30$ to $40 \%$ inundation, similar to findings of increased flooding effects on biomass allocation patterns in Mediterranean Spartina maritima (Wong et al. 2015). Kirwan \& Guntenspergen (2015) found that root-to-shoot ratios were largely invariant along inundation gradients in $S$. americanus and $S$. patens. In our study, inundation effects on root-to-shoot ratios were relatively weak, and variable responses among species suggest different growth responses to inundation. For instance, increasing flooding affected $S$. pacifica shoots more strongly than roots, but J. balticus roots + rhizomes more strongly than shoots (Fig. 3).

Elucidating above- versus belowground growth responses to inundation gradients is important for evaluating SLR effects on different vascular plant functions in tidal wetlands. For example, disproportionate loss of aboveground biomass may reduce trapping and deposition of inorganic material in surface soils, rendering wetlands more dependent on belowground organic matter inputs to maintain elevation with rising water levels. Declines in shoot growth may also impact plant canopy complexity with negative consequences for marsh-dependent fauna. In contrast, significant loss of belowground production with relative SLR may destabilize marsh soils, particularly at channel edges where waves and tidal currents may weaken soil cohesion (see Deegan et al. 2012 for a nutrient example), even if aboveground capacity to trap sediments remains unaffected.

Other abiotic and biotic factors are likely to interact with inundation to determine spatial patterns of plant productivity in tidal marshes. For instance, recent work by Schile et al. (2011) on S. pacifica in northern California suggests that soil drainage patterns, not just total inundation time, may be an important determinant of plant production. Plants in well-drained soils were more productive than those on the marsh plain. Elevated salinity, an important abiotic stressor for vascular plants, may also interact with flooding to negatively impact production (Janousek \& Mayo 2013, Snedden et al. 2015). In fact, variation in inundation may create vertical salinity gradients (through evaporation in warmer areas, or fluvial contributions in estuaries with high freshwater inputs) that also affect productivity. Langley et al. (2013) found that addition of nitrogen, or nitrogen $+\mathrm{CO}_{2}$, modified the elevation at which $S$. patens showed maximum production and increased production in S. americanus at higher flooding levels relative to controls. In contrast, Wong et al. (2015) determined that the negative effects of increased flooding on $S$. maritima growth were greatest under elevated nutrient conditions.

Interspecific plant interactions (not present in our mesocosms because we isolated plants from neighbors) may also affect plant growth along inundation gradients, much as they impact overall plant distribution in tidal marshes (Pennings et al. 2005). There are few published data available on inundation effects on mixed species assemblages in controlled experiments. However, Langley et al. (2013) used field mesocosms to study inundation, nitrogen and $\mathrm{CO}_{2}$ effects on a mixed assemblage of $S$. americanus and $S$. patens and found that the relative abundance of the species changed along the inundation gradient. Variation in flooding may contribute to a shift in the competitive balance among co-occurring species, as seen in a greenhouse manipulation of inundation and nutrients with Distichlis spicata and S. patens (Watson et al. 2015). To better understand how whole marsh assemblages may respond to SLR, other experimental designs such as manipulation of marsh inundation by passive weirs may be useful (Cherry et al. 2015).

\section{Productivity versus field abundance}

Determining current patterns of plant distributions with respect to conditions for optimal productivity are important for evaluating near versus long-term effects of SLR on marsh structure and function. We found high abundance of C. lyngbyei, J. balticus and $B$. maritimus in field plots at elevations at (or above) those coinciding with maximum productivity in the mesocosm experiments, suggesting that small nearterm increases in relative SLR may have little impact on growth of these species. In contrast, both $S$. pacifica and $S$. foliosa were often abundant in the field at elevations below their estimated maximum productivity levels in the mesocosm experiment. Thus, small levels of relative SLR such as the 17 to $28 \mathrm{~cm}$ rise projected to occur under mid SLR scenarios for several USA west coast locations by the year 2050 (NRC 2012) may have a greater negative effect on marshes dominated by $S$. pacifica and S. foliosa. Similarly, Voss et al. (2013) found that S. alterniflora and Juncus roemerianus in a North Carolina marsh organs study occurred on adjacent marshes below their optimal productivity levels.

For species particularly sensitive to soil saturation, however, the marsh organ experimental design may exacerbate the negative effects of inundation on plant growth because horizontal drainage during low 
tide may be impeded in the PVC pipes. This may affect estimates of optimal productivity in some species such as $S$. pacifica, which has been shown to be sensitive to soil drainage (Schile et al. 2011, but see Mahall \& Park 1976b, who suggested that the distribution of $S$. pacifica is insensitive to soil oxygen availability). If the mesocosms contained more anoxic sediment than un-manipulated marsh at the same tidal elevation, optimal productivity may have been shifted higher in the tidal frame relative to the marsh.

Alternatively, species interactions and inter-specific differences in abiotic tolerances may explain why $S$. foliosa and $S$. pacifica both commonly grew at apparently sub-optimal elevations in the field relative to the mesocosms. S. foliosa may be distributed at lower elevations than its peak productivity because it is outcompeted by $S$. pacifica and/or $B$. maritimus at higher elevations, similar to $S$. alterniflora zonation on the Atlantic coast (Bertness 1991). Along the edges of tidal channels where soil drainage may be greater than on the marsh plain (Schile et al. 2011), S. pacifica may be able to outcompete $S$. foliosa. As the dominant species in the Petaluma marsh, $S$. pacifica probably tolerates a broad range of soil conditions (including high salinity sediments; Mahall \& Park 1976a), so it may frequently grow under sub-optimal conditions. It may be a competitive sub-dominant in local patches (e.g. some high marsh areas occupied by large woody species such as Grindelia stricta and Baccharis pilularis). Our study provides important general data on how several major Pacific coast marsh species respond to gradients of tidal inundation, but further experimentation incorporating variation in soil drainage and salinity, neighbor effects, or other factors will help refine understanding of contemporary ecosystem structure and potential changes with SLR.

\section{CONCLUSIONS}

Above- and belowground plant production are important components of the biogeomorphic response to inundation that shapes tidal wetland elevation (Morris et al. 2002) and of other essential ecosystem functions maintained by tidal marsh vegetation. Our data show species-level differences in functional responses with inundation, suggesting that marsh vegetation composition will play an important role in determining relative SLR effects on specific tidal marshes. In particular, growth of high marsh species such as Salicornia pacifica that are most sensitive to elevated inundation may be least tolerant of relative SLR. Loss of produc- tion in marshes dominated by these species will potentially reduce marsh capacity to keep up with SLR. Relative SLR may also induce shifts in vegetation composition, with drowning marshes becoming more dominated by more flooding-tolerant species. We suggest that incorporation of species-specific productivity-inundation relationships into mechanistic SLR models will produce more accurate projections of local marsh vulnerability to SLR.

Acknowledgements. The project described in this publication was supported by the Southwest and Northwest Climate Science Centers (SWCSC and NWCSC) of the US Department of the Interior, the DOI On The Landscape program, the USGS Climate and Land-Use Research and Development Program, the USGS Western Ecological Research Center in partnership with Oregon State University and a NWCSC graduate fellowship to K.J.B. The US EPA loaned conductivity loggers used in this study and the US Fish and Wildlife Service and California Department of Fish and Wildlife approved site access. We thank W. Chan, J. Converse, S. de la Cruz, L. Curry, C. Davis, J. Day, J. Donald, T. Endicott, M. Hammett, M. Hill, L. Hollander, K. Lovett, B. McKay, C. Norton, K. Powelson, Y. Sanchez, E. Schultz, A. Stargel, D. Steele, S. Stephensen and especially T. Edgarian for research assistance. K. Byrd, J. Yee and anonymous reviewers kindly provided comments on the manuscript. Any use of trade, product, or firm names in this publication is for descriptive purposes only and does not imply endorsement by the USA Government. The findings and conclusions in this article are those of the authors and do not necessarily represent the views of the NWCSC or SWCSC. The United States Government is authorized to reproduce and distribute reprints of this article for governmental purposes.

\section{LITERATURE CITED}

Bertness MD (1991) Zonation of Spartina patens and Spartina alterniflora in a New England salt marsh. Ecology 72:138-148

> Bertness MD, Ellison AM (1987) Determinants of pattern in a New England salt marsh plant community. Ecol Monogr 57:129-147

$>$ Bradley PM, Dunn EL (1989) Effects of sulfide on the growth of three salt marsh halophytes of the southeastern United States. Am J Bot 76:1707-1713

Brophy LS, Cornu CE, Adamus PR, Christy JA and others (2011) New tools for tidal wetland restoration: development of a reference conditions database and a temperature sensor method for detecting tidal inundation in least-disturbed tidal wetlands of Oregon, USA. Prepared for Cooperative Institute for Coastal and Estuarine Environmental Technology (CICEET), Durham, NH

Cade BS, Noon BR (2003) A gentle introduction to quantile regression for ecologists. Front Ecol Environ 1:412-420

Callaway JC, Josselyn MN (1992) The introduction and spread of smooth cordgrass (Spartina alterniflora) in South San Francisco Bay. Estuaries 15:218-226

> Callaway JC, Borgnis EL, Turner RE, Milan CS (2012) Carbon sequestration and sediment accretion in San Francisco Bay tidal wetlands. Estuar Coast 35:1163-1181 
Cherry JA, McKee KL, Grace JB (2009) Elevated $\mathrm{CO}_{2}$ enhances biological contributions to elevation change in coastal wetlands by offsetting stressors associated with sea-level rise. J Ecol 97:67-77

> Cherry JA, Ramseur GS Jr, Sparks EL, Cebrian J (2015) Testing sea-level rise impacts in tidal wetlands: a novel in situ approach. Methods Ecol Evol 6:1443-1451

> Cloern JE, Knowles N, Brown LR, Cayan D and others (2011) Projected evolution of California's San Francisco BayDelta-River system in a century of climate change. PLoS ONE 6:e24465

> Daehler CC, Strong DR (1997) Hybridization between introduced smooth cordgrass (Spartina alterniflora; Poaceae) and native California cordgrass ( $S$. foliosa) in San Francisco Bay, California, USA. Am J Bot 84:607-611

> Deegan LA, Johnson DS, Warren RS, Peterson BJ, Fleeger JW, Fagherazzi S, Wollheim WM (2012) Coastal eutrophication as a driver of salt marsh loss. Nature 490:388-392

Engels JG, Jensen K (2009) Patterns of wetland plant diversity along estuarine stress gradients of the Elbe (Germany) and Connecticut (USA) rivers. Plant Ecol Divers 2: 301-311

> Gleason ML, Elmer DA, Pien NC, Fisher JS (1979) Effects of stem density upon sediment retention by salt marsh cord grass, Spartina alterniflora Loisel. Estuaries 2:271-273

> Hedges LV, Gurevitch J, Curtis PS (1999) The meta-analysis of response ratios in experimental ecology. Ecology 80: 1150-1156

Hester MW, Mendelssohn IA, McKee KL (2001) Species and population variation to salinity stress in Panicum hemitomon, Spartina patens, and Spartina alterniflora: morphological and physiological constraints. Environ Exp Bot 46: 277-297

Hutchinson I (1988) The biogeography of the coastal wetlands of the Puget Trough: deltaic form, environment, and marsh community structure. J Biogeogr 15:729-745

> Janousek CN, Folger CL (2014) Variation in tidal wetland plant diversity and composition within and among coastal estuaries: assessing the relative importance of environmental gradients. J Veg Sci 25:534-545

> Janousek CN, Mayo C (2013) Plant responses to increased inundation and salt exposure: interactive effects on tidal marsh productivity. Plant Ecol 214:917-928

Kirwan ML, Guntenspergen GR (2012) Feedbacks between inundation, root production, and shoot growth in a rapidly submerging brackish marsh. J Ecol 100:764-770

Kirwan ML, Guntenspergen GR (2015) Response of plant productivity to experimental flooding in a stable and a submerging marsh. Ecosystems 18:903-913

Kirwan ML, Megonigal JP (2013) Tidal wetland stability in the face of human impacts and sea-level rise. Nature 504: $53-60$

Kirwan ML, Langley JA, Guntenspergen GR, Megonigal JP (2013) The impact of sea-level rise on organic matter decay rates in Chesapeake Bay brackish tidal marshes. Biogeosciences 10:1869-1876

Langley JA, Mozdzer TJ, Shepard KA, Hagerty SB, Megonigal JP (2013) Tidal marsh plant responses to elevated $\mathrm{CO}_{2}$, nitrogen fertilization, and sea level rise. Glob Change Biol 19:1495-1503

Lee H II, Brown CA (eds) (2009) Classification of regional patterns of environmental drivers and benthic habitats in Pacific Northwest estuaries. US EPA, Office of Research and Development, National Health and Environmental Effects Research Laboratory, Western Ecology Division.
EPA/600/R-09/140

Mahall BE, Park RB (1976a) The ecotone between Spartina foliosa Trin. and Salicornia virginica L. in salt marshes of northern San Francisco Bay. II. Soil water and salinity. J Ecol 64:793-809

Mahall BE, Park RB (1976b) The ecotone between Spartina foliosa Trin. and Salicornia virginica L. in salt marshes of northern San Francisco Bay. III. Soil aeration and tidal immersion. J Ecol 64:811-819

> Marani M, D'Alpaos A, Lanzoni S, Carniello L, Rinaldo A (2010) The importance of being coupled: stable states and catastrophic shifts in tidal biomorphodynamics. J Geophys Res 115:F04004, doi:10.1029/2009JF001600

Morris JT, Sundareshwar PV, Nietch CT, Kjerfve B, Cahoon DR (2002) Responses of coastal wetlands to rising sea level. Ecology 83:2869-2877

> Mudd SM, D'Alpaos A, Morris JT (2010) How does vegetation affect sedimentation on tidal marshes? Investigating particle capture and hydrodynamic controls on biologically mediated sedimentation. J Geophys Res 115, F03029, doi:10.1029/2009JF001566

National Research Council (2012) Sea-level rise for the coasts of California, Oregon, and Washington: past, present, and future. National Academies Press, Washington, DC

Neubauer SC (2008) Contributions of mineral and organic components to tidal freshwater marsh accretion. Estuar Coast Shelf Sci 78:78-88

Nyman JA, Walters RJ, Delaune RD, Patrick WH Jr (2006) Marsh vertical accretion via vegetative growth. Estuar Coast Shelf Sci 69:370-380

> Ouyang X, Lee SY (2014) Updated estimates of carbon accumulation rates in coastal marsh sediments. Biogeosciences 11:5057-5071

Parker JD, Montoya JP, Hay ME (2008) A specialist detritivore links Spartina alterniflora to salt marsh food webs. Mar Ecol Prog Ser 364:87-95

> Pearcy RW, Ustin SL (1984) Effects of salinity on growth and photosynthesis of three California tidal marsh species. Oecologia 62:68-73

- Pendleton L, Donato DC, Murray BC, Crooks S and others (2012) Estimating 'blue carbon' emissions from conversion and degradation of vegetated coastal ecosystems. PLoS ONE 7:e43542

> Pennings SC, Grant MB, Bertness MD (2005) Plant zonation in low-latitude salt marshes: disentangling the roles of flooding, salinity and competition. J Ecol 93:159-167

> Ross AC, Najjar RG, Li M, Mann ME, Ford SE, Katz B (2015) Sea-level rise and other influences on decadal-scale salinity variability in a coastal plain estuary. Estuar Coast Shelf Sci 157:79-92

> Rozema J, Blom B (1977) Effects of salinity and inundation on the growth of Agrostis stolonifera and Juncus gerardii. J Ecol 65:213-222

> Ryan AB, Boyer KE (2012) Nitrogen further promotes a dominant salt marsh plant in an increasingly saline environment. J Plant Ecol 5:429-441

Sánchez JM, Otero XL, Izco J (1998) Relationships between vegetation and environmental characteristics in a saltmarsh system on the coast of Northwest Spain. Plant Ecol 136:1-8

Schile LM, Callaway JC, Parker VT, Vasey MC (2011) Salinity and inundation influence productivity of the halophytic plant Sarcocornia pacifica. Wetlands 31: 1165-1174 
Schile LM, Callaway JC, Morris JT, Stralberg D, Parker VT, Kelly M (2014) Modeling tidal marsh distribution with sea-level rise: evaluating the role of vegetation, sediment, and upland habitat in marsh resiliency. PLoS ONE 9:e88760

Shepard CC, Crain CM, Beck MW (2011) The protective role of coastal marshes: a systematic review and metaanalysis. PLoS ONE 6:e27374

Snedden GA, Cretini K, Patton B (2015) Inundation and salinity impacts to above- and belowground productivity in Spartina patens and Spartina alterniflora in the Mississippi River deltaic plain: implications for using river diversions as restoration tools. Ecol Eng 81:133-139

Sustaita D, Quickert PF, Patterson L, Barthman-Thompson L, Estrella S (2011) Salt marsh harvest mouse demography and habitat use in the Suisun marsh, California. J Wildl Manag 75:1498-1507

Swanson KM, Drexler JZ, Schoellhamer DH, Thorne KM, Casazza ML, Overton CT (2014) Wetland accretion rate model of ecosystem resilience (WARMER) and its application to habitat sustainability for endangered species in the San Francisco estuary. Estuar Coast 37:476-492

Takekawa JY, Thorne KM, Buffington KJ, Spragens KA and others (2013) Final report for sea-level rise response modeling for San Francisco Bay estuary tidal marshes. US Geol Surv Open File Rep 2013-1081, http://pubs. usgs.gov/of/2013/1081/pdf/ofr20131081.pdf

Editorial responsibility: Kenneth Heck Jr., Dauphin Island, Alabama, USA
Thorne KM, Takekawa JY, Elliott-Fisk DL (2012) Ecological effects of climate change on salt marsh wildlife: a case study from a highly urbanized estuary. J Coast Res 28: 1477-1487

- Voss CM, Christian RR, Morris JT (2013) Marsh macrophyte responses to inundation anticipate impacts of sea-level rise and indicate ongoing drowning of North Carolina marshes. Mar Biol 160:181-194

Watson EB, Oczkowski AJ, Wigand C, Hanson AR and others (2014) Nutrient enrichment and precipitation changes do not enhance resiliency of salt marshes to sea level rise in the northeastern US. Clim Change 125: 501-509

Watson EB, Andrews HM, Fisher A, Cencer M, Coiro L, Kelley S, Wigand C (2015) Growth and photosynthesis responses of two co-occurring marsh grasses to inundation and varied nutrients. Botany 93:671-683

Wong JXW, Van Colen C, Airoldi L (2015) Nutrient levels modify saltmarsh responses to increased inundation in different soil types. Mar Environ Res 104:37-46

Woo I, Takekawa JY (2012) Will inundation and salinity levels associated with projected sea level rise reduce the survival, growth, and reproductive capacity of Sarcocornia pacifica (pickleweed)? Aquat Bot 102:8-14

> Zedler JB (1977) Salt marsh community structure in the Tijuana Estuary, California. Estuar Coast Shelf Sci 5: 39-53

Submitted: July 14, 2015; Accepted: March 3, 2016

Proofs received from author(s): March 22, 2016 